\title{
ДИСКУСІї
}

\section{Олександр ГУРжІЙ}

доктор історичних наук, професор, головний науковий співробітник, відділ історії України середніх віків та раннього нового часу, Інститут історії України НАН України (Київ, Україна), oleksandrgurzijoo3@gmail.com ORCID: https://orcid.org/oooo-oooI-694I-4488

\section{Перші роки «дружби та братерства» в українсько-московській торгівлі середини XVII ст.}

DOI: https://doi.org/10.15407/uhj202I.05.203

УДК: $339.5(477):(470+571) \ll 165 »$

\begin{abstract}
Анотація. Мета статті - охарактеризувати непрості взаємини влад України та Московії в галузі торгівлі у середині XVII ст. Методологія дослідження грунтується на принципах історизму й детермінізму. Автор застосував як загальнонаукові (системного аналізу, синтезу, аналогії, абстрагування, узагальнення), так і спеціальні історичні (критичного опрацювання джерел, компаративності, проблемно-хронологічний) методи. Наукова новизна. Уперше порушуються питання наявності всеросійського єдиного ринку й долучення до нього українського національного ринку, на підставі тогочасних першоджерел спростовується чимало тверджень істориків-попередників про нібито «дружні» та навіть «братерські» стосунки в торговому обороті обох країн. Висновки. Вихід у перші роки Національної революції XVII ст. зі складу Речі Посполитої значної частини українських земель значно обмежив зовнішню торгівлю в напрямку Західної Європи, спонукав до активізації ії в бік північного сусіда, а також східних держав. На цьому етапі економічного розвитку гетьманові Б.Хмельницькому вдалося зберегти певну самостійність і порівняно демократичний характер товарообміну із закордонням, спрямувавши свою політику на вигідні взаємини з іноземними негоціантами, зокрема Росії, Польщі, Литви, Греції, частково Кримського ханства й Туреччини.
\end{abstract}

Ключові слова: зовнішні торгівля, негоціанти, Московія, Україна, Річ Посполита, «литовська сторона».

Початок Національної революції українського народу середини XVII ст. помітно позначився на статусі, формах і рівні міжнародної торгівлі не лише України, а й Польщі, Литви, Росії, частково Кримського ханства. Адже поява політико-адміністративного та військово-територіального утворення на чолі з гетьманами чітко засвідчила формування автономного державного суб'єкта у системі європейських відносин. У зв'язку з цим почалася поступова кореляція «традиційних» середньовічних торгових шляхів. Вихід зі складу Речі Посполитої великої частини українських 
земель юридично й ментально перетворило ії торгових людей, колись «своїх» та економічно споріднених для поляків і литовців, на «чужих», а подекуди й «ворогів-конкурентів». Так само, як перед тим польсько-литовські документи визначали московитів. Завжди інтегрована із Західною Європою торгівля Речі Посполитої за таких обставин змусила торговців з України вдатися до активного пошуку нових «партнерів», шляхів, осередків для реалізації сільськогосподарської та промислової продукції, а також цілеспрямованого налагодження власного товарообігу із зарубіжжям. Адже зв'язок зі «старими» польськими та литовськими посередниками якщо й не перервався остаточно, то принаймні відчутно звузився через політичні та воєнні конфлікти. Тому більш масована, ніж у попередній період, переорієнтація на російські ринки виявилася цілком природною - хоча 6 для середини XVII ст. Окрім того, відрив такого потужного міжнародного гравця, яким виявилося Військо Запорозьке, від Речі Посполитої й перетворення його на свого союзника в боротьбі за польську корону повністю вкладалися у великомасштабні плани Москви.

Про початки формування державної політики в Московії щодо українських товарів, які саме і в котрі «государевы городы (тобто міста - О.Г.) пропускать или не пропускать», ішлося у «відписці» брянського воєводи Н.Мещерського в Посольський

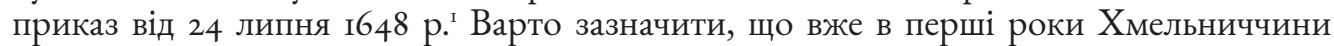
в урядах України та Московії складалися неоднозначні підходи щодо питань міждержавної торгівлі, зрозуміло, утверджувалися й різні погляди на взаємини з іноземними негоціантами. Так, якщо радянські історики наполегливо писали про нібито «безкорисливу» економічну допомогу російської влади українцям у боротьбі за незалежність від «шляхетської Польщі»², то на практиці все виглядало інакше та набагато складніше. У грамоті царя Олексія Михайловича в Посольський приказ і безпосередньо хотмизькому воєводі С.Болховському від 22 листопада 1648 р. наказувалося дозволити польським і литовським купцям (ішлося про всіх торгових людей Речі Посполитої, включаючи й українців) «торговать повольною торговлею», але при цьому «государеву пошлину с их товаров велено имать по [...] указу тротив прежнего». Водночас із метою усунення з їхнього боку конкуренції, їм категорично («накрепко») заборонялося привозити на ринки спиртні напої й тютюн, а порушників наказу слід було відправляти «совсем назад за рубеж»³. Проте торгівля забороненими предметами тривала, іï таємна організація відбувалася на прикордонні, в обхід контролюючих установ, на відстані від 3-х до го-ти верст від Хотмизька «в лесах, в крепких местах, и за лесами». Причому тамошні «всякие служлые люди у тех литовських купців вино покупают тайными обычаи и пропиваютца» ${ }^{4}$. Водночас у західному напрямку бойові дії вкрай обмежили просування торгового люду з України на зарубіжні ринки. Можновладці Речі Посполитої часто-густо за безцінь скуповували їхні товари, а то й просто відбирали, закривали проїзд через митниці. 2 (г2) липня, коли козацька рада під Білою Церквою ухвалила укласти перемир'я з Польщею й направити посольство до Варшави, Б.Хмельницький констатував у своїй переговорній

\footnotetext{
1648 г., июля 24. - Отписка брянского воеводы Н.Мещерского в Посольский приказ о пригоне украинскими купцами в Брянский уезд волов для продажи и о разрешении русского правительства украинским купцам свободно торговать в пределах России // Воссоединение Украины с Россией: Док. и мат. в 3 т. - Т.ІІ: Освободительная война украинского народа и борьба за воссоединение с Россией: 1648-1651 гг. - Москва, 1954. - С.65-66.

2 Напр., див.: Сергієнко Г.Я. Великий історичний акт (До 325-річчя возз'єднання України з Росією). - К., 1978. 46 с.; Н̆ого ж. Возз'єднання України з Росією та його історичне значення // Український історичний журнал. - 1979. №1. - C.5-15.

31648 г., февраля 5. - Отписка хотмыжского воеводы С.Болховского в Посольский приказ о торговле украинских купцов в пределах Русского государства // Воссоединение Украины с Россией. - Т.II. - С.7.

4 Там же. - С.8.
} 
інструкції (наказі послам): польським урядовцям, жовнірам і драгунам, кому що сподобається, - «чи кінь добрий, чи зброя, чи що інше, ми віддаємо за півціни, ніби сторгувавшись, а якби не дали, то подумай, козаче-небораче, про себе». При цьому не можна було ховати від жовнірської челяді ані вола, ані корову, а сіно у скиртах і збіжжя в полях, на нивах жате, як власне вони силоміць беруть

Водночас спостерігаємо поблажливе ставлення Б.Хмельницького до князів литовських, котрі нібито брали участь у збройних конфліктах не зі своєї волі, а через ворожу примху. Так, в універсалі від 17 (27) липня 1648 р. гетьман заборонив українським повстанцям чинити «шкоду» в маєтностях литовських можновладців. «Ми 3 давніх часів, - наголошувалося в документі, - користувалися великою милостю і ласкою їх м-тей панів литовських, які брали участь у різних походах його королівської величності і всієї Речі Посполитої». А тому «всім козакам» заборонялося заподіювати кривди панам Великого князівства Литовського 6 .

Ураховуючи той факт, що схожого змісту універсали Б.Хмельницького про «давню дружбу з Литовським князівством, що ніколи проти нас війни не починало та завжди було дружелюбним» ${ }^{7}$, стали явищем непоодиноким, цілком логічно припустити: гетьман планував і надалі розвивати економічні стосунки з його населенням, як це спостерігалося в попередній період.

На початку 1649 р. царська адміністрація на прикордонні з Річчю Посполитою продовжувала ототожнювати українців із «литовцями», принаймні так називали їх в офіційних документах. Типовим прикладом може слугувати «відписка» бобрикського воєводи К.Ушакова на ім'я Олексія Михайловича через Розрядний приказ від 6 лютого. Можновладець сповіщав, що московські «торгові люди» з Бєлгорода, Хотмизька та Вільного провозять усілякі товари вночі, обходячи місто Бобрик і тамтешню заставу. А продукцію вивозять головним чином у «Литву» (Україну), особливо недозволені хліб і мед. Звідти ж поставляють заборонений тютюн. Зокрема у Веприку мешканці Вільного О.Кудрявець, С.Климов і Я.Пшеничний продали 40 пудів меду. Причому торговці проклали свій шлях, що оминав заставу в Бобрику на відстані го верст ${ }^{8}$.

Невпорядкованість у торговельній сфері між Московією та Україною нерідко призводила до певних колізій і значних непорозумінь торгових людей із царською адміністрацією. Так, курський воєвода Ф.Лодиженський мав на руках іменний указ про дозвіл українцям вільно торгувати в Курську будь-чим, окрім «вина» (спиртних напоїв) і тютюну, за що ті мали сплачувати державне мито. Коли ж прибулі намагалися купити партії зерна й солі, їм було відмовлено через відсутність указівок та роз'яснень щодо цього від вищої влади'.

Одночасно щось схоже відбувалося в місті Вільному, правда, із тією принциповою різницею, що українські торгові люди, «як православні християнської віри», домагалися дозвільного проїзду в різні російські місцевості на підставі таких причин:

\footnotetext{
5 Письмо Хмельницкого к его милости, блаженной памяти королю Владиславу IV, из Белой Церкви, 2 июля 1648 г. // Памятники, изданные Временной комиссией для разбора древних актов. - Т.I. - Отд.ІІІ. - К., 1848. - С.118-125.

${ }_{6}$ 1648, липня 17 (27). Паволоч. - Універсал Богдана Хмельницького про заборону Запорозькому Війську чинити шкоди в маєтностях литовських панів // Z dziejów Ukrainy. - Krakow, 1912. - S.410; Документи Богдана Хмельницького: 1648-1657. - К., 1961. - №18. - C.58-59.

7 1649, лютого 27 (березня 6). Переяслав. - Універсал Богдана Хмельницького про заборону козакам чинити будь-які кривди у Литовському князівстві // Універсали Богдана Хмельницького 1648-1657. - К., 1998. - С.89-90.

81649 г., февраля 6. - Отписка бобринского воеводы К.Ушакова в Разрядный приказ о вывозе русскими купцами в украинские города хлеба и мёда и о переходе беглых русских людей на Украину // Воссоединение Украины с Россией. T.II. - C.131.

9 1649 г., март 3. - Отписка курского воеводы Ф.Лодыженского в Посольский приказ о закупке украинскими купцами в Курске хлеба и соли // Там же. - С.135.
} 
І) вони мешкали на гостиних дворах, а тому реалізацією продукції займалися постійно і професійно; 2) їздили «з торгом» у такі «государеві міста», як Путивль, Севськ, Курськ, Рильськ, Бєлгород, Оскол та ін.; 3) промишляли «безпрестанно и обозами большими, в обозе человек по гоо и по 50 и больши, на дни обоза по 2 и по 3». Причому товарообіг з обох сторін включав і заборонені хліб, сіль, мед (березень I649 p. $)^{\mathrm{IO}}$.

На підставі довготривалої практичної діяльності ставилося питання про законність такого виду торгівлі між московитами й українцями з «литовської сторони». Останні, як бачимо, хотіли видавати бажане за реальність.

Примітною особливістю торгівлі стало постачання «литовськими людьми» в Московію селітри. Справа водночас була економічно вигідною й непростою, адже ця речовина на найвищому рівні визначалася як стратегічна. Так, у січні 1648 р. у Хотмизьку князь С.Болховський купив 44,5 пудів селітри в постачальників з України по г руб. го алтин і $з$ деньги за пуд. У березні наступного року він перевіз їі до Москви за царським указом, де й передав уповноваженим особам Пушкарського приказу Усе це відбувалося з відома та під контролем Олексія Михайловича, адже селітра використовувалася при виготовленні пороху.

У І649 р. цар видав спеціальну грамоту, яка нібито дозволила приїжджім «з литовської сторони запорозьким черкасам» безмитно торгувати в Путивлі й повіті ${ }^{12}$. Того року побачили світ чимало указів і розпоряджень, котрі засвідчили факти паралельної торгівлі Московії з Україною та Польщею як самостійними суб'єктами ${ }^{13}$. Водночас у Кремлі прагнули забезпечити якомога більше «свободи» своїм торговим людям у Польщі й Литві, а купців із «литовської сторони» практично не звільняли від митних зборів. У цьому проявлялася особлива позиція Москви ${ }^{14}$.

Тоді ж у Хотмизькому повіті приїжджі торгові люди з України зумовили справжній бум, скуповуючи зерно, сіль, мед. Причому вигідність від купівлі та продажу забороненої продукції спричинила долучення до справи жителів не тільки Хотмизька, але й Бєлгорода, Рильська, Яблонова, Курська, Корочі, Карпова, Комарицької волості та ін. У результаті, за запевненням хотмизького воєводи К.Арсеньєва, місцеві мешканці «от литовських и от хотмышан торговых людей хлебом и солью оскудели». А тому він укотре запитував, як йому чинити у цьому випадку, адже указів від царя щодо цього не надходило ${ }^{15}$.

У зв'язку з періодичними загостреннями на українсько-польському фронті, торгові люди «з литовської сторони», закупивши чи спродавши продукцію на російських ринках, масово поверталися до своїх домівок, а значна частина їх долучалася до війська Б.Хмельницького, беручи активну участь у бойових операціях. Ось як про це писав цареві путивльський воєвода Н.Плещєєв у червні 1649 р.: «И ныне, государь, в Путивле и Путивльском уезде черкас и мещан, литовских людей, нет, и приезду, государь, в Петивль из литовские стороны мещаном, литовским людем, ныне стало

\footnotetext{
${ }^{10} 1649$ г., марта 9. - Отписка вольновского воеводы Ф.Арсеньева в Разрядный приказ о проезде через г. Вольный украинских купцов в Россию и русских купцов на Украину // Там же. - Т.II. - С.137.

${ }_{11} 1649$ г., марта 20. - Память из Разрядного приказа в Пушкарский приказ о приёме селитры, купленной у украинских торговых людей в январе 1648 г. // Там же. - С.164.

121649 г., марта 21. - Грамота из Посольского приказа путивльскому воеводе Н.Плещееву о разрешении украинским купцам торговать в Путивле и в Путивльском уезде без уплати таможенных пошлин // Там же.

${ }_{13}^{13}$ Российский государственный архив древних актов (далі - РГАДА). - Посольский приказ. Сношения России с Польшей. 1649. - Д.1. - Л.23-26, 75-76, 88, 121-122 и т. д.

${ }_{14}^{14}$ Акты, относящиеся к истории Южной и Западной России. - Т.ІІІ. - Санкт-Петербург, 1861. - Доп. - С.111-112.

${ }^{15} 1649$ г., марта 23. - Отписка хотмыжского воеводы К.Арсеньева в Посольский приказ о закупке русскими и украинскими купцами в пограничных городах России большого количества хлеба, соли и мёда для вывоза на Украину // Воссоединение Украины с Россией. - Т.ІІ. - С.166.
} 
мало потому, что [...] все черкасы и мещане высланы в полки к гетману черкаскому к Богдану Хмельницкому» ${ }^{16}$.

Про ставлення українського гетьмана до торгівлі з поляками може свідчити спроба обумовити це питання з королем Речі Посполитої у спеціальних статтях-угодах кінця I649 р. Так, Іо-й пункт передбачав вільний, без усіляких «зацепок», проїзд усіх станів українців у Білорусь, до поляків і литовців «для торгового промислу». Своєю чергою католикам дозволялося реалізовувати свою продукцію на всій території Війська Запорозького, включаючи Київ. Суворих обмежень зазнавали євреї, котрим заборонялося мешкати й торгувати в Києві та «за Днепром». Більше того, за порушення цього розпорядження їх передбачалося грабувати й відправляти на постійні місця проживання. При цьому «повольне» шинкування дозволялося реєстровим козакам, а іншим особам - лише через орендування ${ }^{17}$. Правда, тоді гетьманська пропозиція не здобула схвалення польської сторони.

Навіть розмови у вищих урядових колах Московії про безмитну торгівлю українців, усілякі обіцянки та запевнення про поблажливе ставлення у цій справі спонукали Б.Хмельницького відповідним чином реагувати на них. А тому у відповідь він «и все Войско Запороское царському величеству на ево государеве милости, что поволил в своїх государевых городех Запороскому Войску хлеб и соль и всякие товары покупать и с торговых их людей пошлин имать не велел, челом бьют». Зі свого боку гетьман обіцяв, що «и царского величества с торговых людей, которые учнут приезжать в Запороскую землю для торгового промыслу, в Киев и в иные городы, пошлин и тамги имать не велю, и въезжать в свои городы и оберегать их велю, чтоб им нихто кривды не чинил» ${ }^{18}$.

Отже козацький провідник прагнув і передбачав створення широкого міждержавного поля для безмитної, вільної й гарантованої з боку влади торгівлі. Проте насправді, як того вимагав Розрядний приказ, ішлося, щоб не брати з українців «лишних пошлин» і не робити їм «тесноты [...] и никакого дурна» від «городских и от уездных людей ${ }^{19}$.

У 1649 р. царський уряд посилив боротьбу проти конкуренції з іноземними купцями, ліквідувавши більшість їхніх привілеїв і відвівши їм для торгівлі головно Архангельськ. Так, в іменному указі від г червня наголошувалося, що вони повинні «со всеми своими животы ехать за море, а торговать с московскими людьми всякими товарами, приезжая из-за моря, у Архангельского города, а к Москве и в города с товарами и без товаров не ездить». Упродовж 20-зо років схожих економічних обмежень зазнали голландські, німецькі, італійські й деякі інші негоціанти ${ }^{20}$. Звичайно, такі заходи московська влада пояснювала не конкуренцією, а порушенням норм торгівлі та зловживаннями з боку іноземців. Тоді ж було значно підвищено мито для приїжджих західних торговців, збільшено товарообіг із країнами Сходу.

Характеризуючи економіку Російської держави кінця І640-х рр., радянський історик О.Касименко наголошував на тому, що розвиток продуктивних сил цієї країни, зростання великого купецького капіталу й ринкових відносин, зміцнення

\footnotetext{
${ }^{16} 1649$ г., июля 28. - Отписка путивльского воеводы Н.Плещеева в Разрядный приказ о выезде из Путивля и Путивльского уезда на Украину всех украинцев, покупавших хлеб и соль, для участия в походе Богдана Хмельницкого // Там же. - С.228.

${ }_{17} 1649$ г., декабрь. - Записка русского гонца Г.Кунакова, ездившего с царской грамотой к польскому королю в Варшаву, о событиях в Польше и на Украине после заключения Зборовского договора... // Там же. - С.304.

${ }_{18} 1649$ г., марта 13 - мая 22. - Статейный список посла русского правительства Г.Унковского к Богдану Хмельницкому // Там же. - С.153.

${ }_{19}$ РГАДА. - Разрядный приказ. Белгородский стол. - Столб.288. - Л.125.

${ }^{20}$ Покровский С.A. Внешняя торговля и внешняя торговая политика России. - Москва, 1947. - С.58.
} 
економічних зв’язків між окремими частинами та їх місцевими ринками - усе це сприяло формуванню єдиного всеросійського ринку ${ }^{21}$. На нашу думку, мало чим підтверджена, ця принципова оцінка викликає цілий ряд питань, сумнівів і навіть заперечень. По-перше, розвиток промисловості та сільського господарства в Московії набагато відставав від передових європейських країн; по-друге, «великий купецький капітал» значною мірою зазнавав втручання влади у своє функціонування, державна казна неабияк негативно впливала на нього всілякого роду монополіями, орендуванням, порівняно високими податками тощо; по-третє, відсутність банківської системи та практично ручне регіональне управління торгівлею й економікою великих центрів неабияк гальмувало зміцнення зв'язків між окремими землями; по-четверте, за логікою виробничих відносин, мав існувати провідний центральний осередок, до якого б тяжіли інші області, найкраще на цю роль могла претендувати Москва, але у цьому аспекті ії тоді помітно випереджав Архангельськ - реально перетворений на домінантний населений пункт міжнародної торгівлі (на відміну від столиці, де іï було заборонено); по-п’яте, відчутно обмежило торговельну ініціативність і спроможність «низів» рішення Земського собору I649 р. про закріпачення селян ${ }^{22}$. Останнє, на думку Я.Котілайне, дуже збіднювало економіку країни, адже домінуюча частина населення існувала на межі прожиткового мінімуму, а до обмеженості платоспроможності селян додавалася ще й руйнація їхніх господарств унаслідок періодичних місцевих повстань. Тому доходи державної казни від селянської торгівлі ставали мінімальними ${ }^{23}$. Отже, на наше переконання, на середину XVII ст. всі необхідні умови для формування єдиного всеросійського ринку остаточно не склалися. Тим більше невиправдана інша теза О.Касименка, а саме: «Характерною і знаменною історичною особливістю цього процесу було те, що Україна до певної міри включилася в єдиний всеросійський ринок ще до возз'єднання з Росією» ${ }^{24}$.

Наведенні нами фактичні дані спростовують і концепцію іншого радянського історика - В.Веселаго - про те, що нібито в період Хмельниччини «жвавий обмін товарами призводив до суспільного поділу праці між російськими і українськими землями, сприяв поступовому утворенню економічних районів, до складу яких увійшли різні області Росії та України» 25 . Така, м'яко кажучи, історична недостовірність цілком очевидно з'явилася внаслідок появи «тез» про «зоо-річчя возз'єднання України з Росією» (1954 р.).

На здогад Ф.Шевченка, «лише десь» від середини XVII ст. у сфері економіки почали складатися національні зв'язки ${ }^{26}$. І як тоді могло відбуватися на практиці економічне «злиття» між обома народами, коли дуже підозріливі щодо українців представники вищої царської адміністрації нерідко сприймали й називали останніх в офіційних документах «розбійниками», «крадіями», «зрадниками». Так, путивльському воєводі С.Прозоровському наказувалося пильно стежити за українцями, щоб «из литовские стороны и из городов боярские холопи и розбойники и тати (грабіжники - О.Г.) и иные никакие воровские люди жить для измены и для всякого

\footnotetext{
${ }^{21}$ Касименко О.К. Російсько-українські взаємовідносини 1648 - початку 1651 р. - К., 1955. - С.192.

22 Див.: Несколько документов к истории Соборного уложения и Земского собора 1648-1649 гг. / Сост. П.Смирнов. Москва, 1913. - 20 с.; Соборное уложение 1649 г. // Российское законодательство X-XX вв.: В 9 т. - Т.3: Акты земских соборов. - Москва, 1985. - С.83-257.

${ }^{23}$ Kotilaine J.T. Russia's Foreign Trade and Economic Expansion in the Seventeenth Century: Windows on the Word. Leiden, 2005. - P.8.

${ }^{24}$ Касименко О.К. Російсько-українські взаємовідносини 1648 - початку 1651 р. - С.192.

${ }_{25}$ Веселаго В.В. Принципи економічної політики Богдана Хмельницького // Нариси з історії економічної думки на Україні. - К., 1956. - С.89.

${ }^{26}$ Шевченко Ф.П. Політичні та економічні зв’язки України з Росією в середині XVII ст. - К., 1959. - С.408.
} 
воровства в Путивль и в Путивльской уезд ни к кому не приходили и измены 6 за рубеж ни от ково отнюдь не бывало» ${ }^{27}$. Побоювався, щоб «какое дурно не учинилось» від українців, і воєвода Н.Плещєєв ${ }^{28}$.

На початку І650 р. московський уряд, через недружні заходи з боку влади Корони Польської й Великого князівства Литовського, заборонив вивіз хліба на продаж через кордон із Річчю Посполитою. У зв'язку з цим із Посольського приказу вяземському воєводі М.Прозоровському було відправлено спеціальну грамоту за підписом Олексія Михайловича. Причому наказувалося «ученить заказ крепкой под смертною казнью, чтоб [...] руские всяких чинов люди за рубеж в литовскую сторону хлеба на продажу отнюдь не возили и их литовским людем не продавали». Кожен, хто порушить заборону, підлягав страті. У грамоті неправдиво зазначалося, що нібито раніше в усіх прикордонних містах полякам і литовцям «обид и задоров отнюдь не чинили, и хлебные и всякие запасы продаваны им беззаборонно» 29. Зрозуміло, що такого змісту суворий «заказ» законодавчо поширювався й на українців, адже ті могли самочинно транспортувати куплену продукцію в межі Польщі чи Литви.

Проте, спираючись на історичні факти, слід зазначити: навіть найсуворіші заходи з боку Москви не могли припинити зарубіжну торгівлю найнеобхіднішими товарами. На те було чимало як суб’єктивних, так і об’єктвних причин (практична неможливість повного перекриття кордонів для товарообігу, корумпованість адміністрації, невизначеність місцевого законодавства тощо). Навіть звичайні життєві фактори могли зумовити вимушене порушення нормативних актів. Так, хлібний недорід і великий голод у «литовській стороні» змусив масу поляків, білорусів та українців шукати «прокорм» у «государевій країні», тобто купувати їстівні припаси і транспортувати їх за кордон. Частково брянський воєвода Н.Мещерський дозволив продавати їм зерно, возів на 5 або 6, але здебільшого наказував: «Многим людем хлебных запасов продавать и на товар менять не велеть». А тому торговельні операції найчастіше проводились таємно, в обхід митниць, застав та адміністрації. Водночас Н.Мещерський, використовуючи ситуацію, вивчав питання, де можна найдешевше купити хліб, щоб потім перепродати з найбільшою вигодою. Про що й інформував царя ${ }^{30}$.

Як видно зі змісту документа, вища влада Московії не скасувала заборону на торгівлю хлібом і вивіз його в Україну та Білорусь, навіть незважаючи на великий голод в окремих регіонах цих країн. Проте впорядники збірки «Воссоединение Украины с Россией», усупереч історичній правді, «не посоромились» визначити відписку воєводи як «приказ» про вивіз великої кількості зерна українцям і білорусам.

Знову ж таки звернемо увагу на ще одне фальшування документа впорядниками названого видання. Так, «Память из Посольского приказа в приказ Большого прихода» вони класифікують як дозвіл українцям безмитно торгувати в Путивлі й повіті ${ }^{{ }^{1}}$. Проте йдеться тут не про офіційний дозвіл, а лише про постановку питання щодо безмитної торгівлі. Адже Б.Хмельницький і все Військо Запорозьке «молили» про те государя неодноразово. Нібито і грамота царя тамтешньому воєводі була

\footnotetext{
${ }_{27}$ РГАДА. - Разрядный приказ. Севский стол. - Столб.168. - Л.165-166.

${ }^{28} 1649$ г., июня 20. - Отписка путивльского воеводы Н.Плещеева в Посольский приказ о положении на Украине и о том, что в Путивльский уезд приехало большое количество украинцев // Воссоединение Украины с Россией. T.II. - C.212.

${ }^{29} 1650$ г., января 3. - Грамота из Посольского приказа вяземскому воеводе М.Прозоровскому о запрещении вывоза хлеба в Польшу и Литву // Там же. - С.318-319.

${ }^{30} 1650$ г., января 9. - Отписка брянского воеводы Н.Мещерского в Разрядный приказ о вывозе из Брянского уезда большого количества хлеба на Украину, в Белоруссию и Смоленщину // Там же. - С.322-324.

${ }^{31}$ Причому, зазначимо, масово заселених українцями.
} 
«дозвільна» з цього приводу. Проте з'ясування проблеми боярином І.Хованським, думним дворянином Б.Нарбековим і дяком І.Патрикєєвим показало таке: «А о литовских купцех, чтоб им в Путивле и в Путивльском уезде торговать безпошлино, в той государевой грамоте не написано» ${ }^{2}$.

Зате з Путивля та Комарицьких волостей, користуючись голодом у Києві й в інших «городех за рубежем», де хліб «добре дорог», торговці з Московської держави отримували значні бариші ${ }^{33}$. Більше того, траплялися випадки пограбування українських торгових людей царськими воєводами. Як то, наприклад, учинив 1650 р. оскольський воєвода Ф.Ловчиков, відібравши товари в київського купця Мезинського. Українська сторона мусила відреагувати відповідним чином. Б.Хмельницький залагодив справу мирно, наполягаючи на рівних правах у торгівлі між Військом Запорозьким і Московією34. Для наведення порядку у цій справі гетьман запропонував вищому царському керівництву поставити на кордоні російських «судних» осіб, а зі свого боку обіцяв призначити спеціальних наглядачів - полковника або сотника, котрі «з обох сторон угледіти мают [...] правдиве і без укривженя» ${ }^{35}$.

Проте, як зазначено в першоджерелах, конфлікти між московськими та українськими купцями тривали й надалі, принаймні до кінця I65o р. Негативно ставилися до перших на території Речі Посполитої. До царя надходила інформація, що в «польских и литовских городех паны и урядники [...] государевых людей всех [...] ныне, засодя держат. А товары де, [...] их, запечатав, держат в лавках, а к лавкам де, [...] приставили стеречь приставав, а на корм (тобто харчування - О.Г.) де, [...] государевым людем выдают из их же животов, чем бы им быть сытым» ${ }^{36}$.

У І65I р. неузгодженість правових норм у сфері торгівлі між українською й московською сторонами тривала: продовжувалися грабунки майна купців урядниками, з'ясування конфліктних ситуацій на середньому та найвищому рівнях адміністрацій ${ }^{37}$. Вирішення окремих справ розтягувалося на багато місяців. Не припинялися й розмови на побутовому рівні про можливості та перспективи вільно «с товары итти» в обидві країни ${ }^{38}$. Аж ніяк не вирішували цю проблему ані жалувана грамота царя гетьманові «и всему Войску Запорожскому о сохранении их прав и вольностей» від 27 березня I654 р., ані грамота Олексія Михайловича Б.Хмельницькому «с подтверждением всех прав и вольностей Войска Запорожского» від І2 квітня того ж рокуз9.

Як зазначали тогочасні документальні джерела, вагому частку в комерційній справі московитів із представниками «литовської сторони», особливо в неврожайні періоди, становило зерно. Про значущість такого виду торгівлі маємо певну

\footnotetext{
321650 г., января 21. - Память из Посольского приказа в приказ Большого прихода о разрешении беспошлинно торговать в Путивле и в Путивльском уезде // Воссоединение Украины с Россией. - Т.II. - С.324-325.

331650 г., марта 23. - Расспросные речи в Посольском приказе греков Х.Мануйлова и Р.Прокофьева, прибывших с вестями о неурожае на Украине и о продаже в украинских городах хлеба, доставленного из России // Там же. C.354-355.

${ }_{34}$ РГАДА. - Посольский приказ. Сношения России с Польшей. 1650. - Д.1. - Л.366-371, 415-447.

${ }^{35} 1650$ г., августа 3. - Лист Богдана Хмельницкого, посланный из Переяслава белгородскому воеводе Б.Репнину... // Воссоединение Украины с Россией. - Т.ІІ. - С.380-381.

${ }^{36} 1650$ г., мая 28. - Отписка севских воевод 3.Леонтьева и Н.Кириллова в Разрядный приказ о защите украинскими казаками и мещанами русских людей от притеснений, чинимых польской администрацией на Украине // Там же. C.366-367.

${ }^{37} 1651$ г., февраль. - Челобитная путивльских купцов С.Дрюпина и других с просьбой послать Богдану Хмельницкому грамоту о возвращении им товаров, которые у них забрал в Ромнах и Гадяче киевский купец В.Мезинский // Там же. T.III: 1651-1654 гг. - Москва, 1954. - С.13-14.

${ }^{38} 1653$ г., марта 2. - Письмо котельвянского сотника Г.Триполева и атамана В.Кислицы вольновскому воеводе В.Новосильцову... // Там же. - С.254.

39 Там же. - C.566-570, 572-573.
} 
оціночну характеристику у звідомленнях «комісара» в Москві I. де Родеса шведській королеві Христині в I65o-х рр. Зокрема він писав:

«Що стосується хліба з усієї Росії, то він також (поряд із сіллю та осетровою ікрою - О.Г.) належить його царській величності та абсолютно жодній приватній особі не дозволяється ним торгувати ${ }^{40}$. Ця торгівля за нинішніх одного за іншим дорогих (голодних - О.Г.) років, що настали, доставила його царській величності багато доходів, особливо за минулі 4 роки, упродовж яких наказано щорічно збирати майже 200 ооо четвертей ${ }^{41}$ хліба, через що той скуповується по всій країні й з усіх місць звозиться до Вологди».

За даними автора листа, у Казанській, Нижегородській і навколишніх областях четверть хліба купувалася за І2-25 коп., у Московській - за 50 коп., в Ярославській, Ростовській, Вологодській - за 36-5о коп. Доходи ж від продажу зерна становили понад I млн райхсталерів, якщо воно йшло за кордон. Чимало товарів привозили іноземці в російські міста, до яких, безперечно, долучалися й торгові люди з України ${ }^{42}$. Причому хліб за рубіж вивозився не кожного року, а лише тоді, коли ціна на нього була найвищою.

Як би там не було, за тодішніх тяжких умов продовжував функціонувати товарообмін між жителями України, Туреччини, Криму, Молдови, Валахії, інших країн. Правда, за таких обставин експорт в українські землі домінував над імпортом. У І65o-х рр. почала проступати певна спеціалізація в торгівлі. Наприклад, виокремлювалися реалізатори хліба, худоби, солі, спиртних напоїв, тютюну тощо. Навіть з'явилися їх назви: «тютюнники», «табачники» й т. д. Адже різні товари нерідко передбачали спеціальні шляхи транспортування, наприклад контрабандні («заборонені»), перегін худоби. Війна скорегувала вихід на західноєвропейські країни. Через руйнацію господарства українці потребували дедалі більше промислових товарів, особливо тканин, знарядь праці, металевих виробів, галантереї тощо. Усе це у великій мірі постачалося з-за кордонуㄱ.

Через ряд зовнішньополітичних причин на той час почала знижуватися й економічна спроможність Московії, зокрема звузилися іï зв'язки із Заходом, частково зі Сходом. Наприклад, звелася нанівець торгівля через Астрахань, що зумовило відхід із процесу значної території та попередньо прокладених через неї традиційних шляхів.

Варто зазначити й таке. Попри розпал бойових дій, уже на початку І65o-х pp. Б.Хмельницький у деталях намагався оформити державницький підхід щодо зовнішньої торгівлі, оподаткування прибулих негоціантів. Найбільш показовим у цьому контексті, очевидно, слід уважати гетьманський універсал, виданий 28 квітня (8 травня) 1654 р. у Чигирині О.Стоматаєнку на збирання податків з іноземних купців. Безпосередньо він поширювався на всю старшину та «чернь» Війська Запорозького, а також торговців «чужоземских и вшелякои кондиціи людем». При цьому Б.Хмельницький переглянув давні збори - «екзакцію скарбовою од купцов чужоземских», і в першу чергу росіян, греків, вірмен, турків, та визначив сплату податків у таких розмірах: від

\footnotetext{
${ }^{40}$ Це явне перебільшення. Очевидно, ішлося про необхідність отримання офіційного дозволу та про сплату податків у державну казну.

${ }^{41} 1$ московська четверть становила 6 пудів зерна або 5 пудів борошна.

${ }^{42}$ Состояние России 1650-1655 гг. по донесениям Родеса / Сообщ. Б.Курц // Чтения в Обществе истории и древностей российских. - Кн.II. - Москва, 1915. - С.157-173.

43 Крип'якевич І.П. Богдан Хмельницький. - Вид. 2-ге, випр. і доп. - Л., 1990. - С.209.
} 
40 соболів - 6 золотих; 40 куниць - 2 золотих; бунта (в'язки) лисячих шкірок - 2 золотих (поставки з Росіі); а з інших «товаров московских» - від гоо талярів битих ${ }^{44}$ по 5 золотих; із турецьких товарів: єдвабів, коберців, мусульбесів, завоїв, киндяків ${ }^{45}$, килимів, поясів, «инших дробных» товарів - від гоо талярів полевкових ${ }^{46}$ брати по 2 битих, від кожної кіпи габи ${ }^{47}$ по леву ${ }^{4}$. Якби хтось з іноземців на українських землях видобував золото, срібло, дорогоцінне каміння чи перлини, то з них із кожних гоо талярів брати по 5 золотих. Якщо іноземний купець намагався таємно вивезти набутий товар, то в нього його могли відібрати, а винуватця навіть фізично покарати ${ }^{49}$. Як бачимо зі змісту документа, мова безпосередньо про різноманітний московський і турецький товар, за який збиралося мито валютою до Військового скарбу.

Водночас у зовнішньоторговельній політиці гетьманського уряду чітко простежувався напрям до спрощення й узагальнення митних зборів. Беручи до уваги Торговельну уставну грамоту (1654р.) Московії, яка передбачала розмір вивізного та ввізного мита у $2 \%$ від вартості транспортованих товарів, він учинив так само. При цьому регіментар, усвідомлюючи вагомість накопичення у країні власне золотих монет, обмежив вивіз дорогоцінних металів ${ }^{\text {s。 }}$ Окрім того, деякі факти свідчать, що він, надаючи перевагу грошовому обігу, намагався замінити панщину на еквівалентний

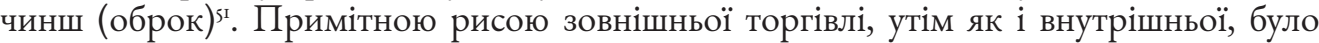
те, що прибутки від неї важко враховувалися при складанні державного бюджету, а тому не затверджувалися нормативно адміністрацією, часто визначалися реальними можливостями та потребами даного періоду. Вони ніби розчинялися серед доходів Військового скарбу, які у сумі перевищували 2 млн польських злотих. Спільним для грошового обігу в Україні та Московії вочевидь стало широкомасштабне застосування різноманітних іноземних монет (валют).

Багато уваги гетьман приділяв зв’язкам із Грецією, а купцям - вихідцям звідти, котрі постійно мешкали в Ніжині, надавав значні пільги, брав під свою протекцію та «оборону». Пояснення такій позиції знаходимо в універсалі Б.Хмельницького від 2 (І2 травня) I657 р., за порушення якого загрожувало суворе покарання:

«Иж мы, приохочуючи греков купцов, абы в сторону нашу з розными товарами прыежджаючи вигодою людем были, мети хочем и суворо росказуем, а жебы жаден по местах и местечках украинных гандле отправуючих, албо перемешкиваючих до права (тобто підпорядкування - О.Г.) полковницкого, козацкого и меского потягать не важился з полковников за се, асавулов, атаманов, войтов, бурмистров, абы жаден о них судить и декретами окрывать не смел, срого напоминаем» ${ }^{52}$.

\footnotetext{
${ }_{44}$ Таляр битий - срібна монета, еквівалент 3 польських злотих.

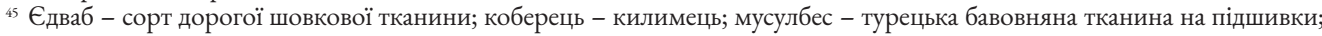
киндяк - турецька бавовняна тканина.

${ }_{46}$ Таляр полевковий - монета нижчої вартості, ніж таляр битий.

${ }^{47}$ Кіпа габи - 100 відрізів турецького білого сукна.

${ }^{48}$ Турецька монета.

49 1654, квітня 28 (8 травня). Чигирин. - Універсал Богдана Хмельницького Остафієві Стоматаєнку на збирання податків з іноземних купців // Центральний державний історичний архів України, м. Київ. - КМФ-9. - Оп.3. - Спр.10; Універсали Богдана Хмельницького. - К., 1998. - С.142-143.

${ }^{50}$ Акты, относящиеся к истории Южной и Западной России. - Т.III. - C.507-508.

${ }^{51}$ Grabowski A. Ojczyste spominki w pismach do dziejow dawnej Polski. - Krakow, 1945. - S.85-86.

52 Лист гетмана Б.Хмельницкого, данный в Чигирине 2 мая 1657 года приезжающим на Украину для торговли грекам... // Федотов-Чеховский А. Акты Греческого нежинского братства. - К., 1884. - С.65-66.
} 
Найбільш компактно, громадою зі своїми правами, на території Гетьманщини греки-купці проживали в Ніжині. Їм дозволялося торгувати «безмытне волно» ${ }^{33}$.

На початку 1650-х рр. Б.Хмельницький неабияк розраховував на налагодження продуктивних економічних взаємин із Туреччиною й, відповідно, Кримським ханством. Османським посланцям він нібито заявив: «Я не відмовляюсь від союзу та дружби з імператором (султаном - О.Г.), готовий тримати з ним мир, як подарунок Божий і людині користь»54. Саме тоді у Чигирині - резиденції володаря булави було розроблено проект документа «Договір із господарем турецьким та Військом Запорозьким і народом руським щодо торгівлі на Чорному морі», де визначалися не лише потреби, а й проблеми українських торгових людей. Зокрема в І-му пункті обумовлювалося надання султаном «козацькому війську» та жителям «землі його» свободи плавання й вільного торгу на Чорному, Середземному морях, по всіх островах, портах, річках і містах. У 2-му пункті передбачалося звільнення українських купців від мит, податків на Іоо (або від 30 до 5о) років. А в подальшому така умова скасовувалася та українці й турки зобов'язувалися до сплати рівноцінних зборів. Для офіційного забезпечення купівлі - продажу українців турецька сторона повинна посприяти облаштуванню в містах і портах «складних домів» (очевидно, на кшталт «гостиних» будівель). Це обумовлював 3-й пункт. Цікаво, що у Стамбулі та в одному з портових міст України мали перебувати резиденти, у чиї обов'язки входив би нагляд за дотриманням правил торгівлі, захист скривджених купців, видача проїзних документів (4-й пункт). За 5-м пунктом Війську Запорозькому дозволялося будівництво кількох портових осередків нижче порогів і в гирлі Дніпра. На розміщені в них козацькі загони покладався захист торгівлі від «своєвільників». У разі порушення цієї угоди представники обох сторін зобов’язувалися спільно відшукати й покарати винних (7-й пункт). У 8-Із-му пунктах ішлося про форми покарання за недотримання встановлених правил, долю майна у випадку аварії чи смерті його власника, можливість викупу бранців з обох боків тощо 55.

Як бачимо, у плани Б.Хмельницького входила організація масштабної зовнішньої торгівлі на більш демократичних засадах, ніж це було в Московії. На відміну від влади останньої, в Україні гетьманська адміністрація намагалася залучити якомога більше негоціантів і їхніх капіталів у національну торгівлю, для чого надавалися значні пільги, гарантувався захист комерційних інтересів та охорона («протекція»). При цьому в обох країнах просте товарне виробництво, яке зосереджувалося головним чином у великих населених пунктах, створювало лише передумови для формування буржуазних відносин і загальнодержавного ринку.

Наведенні вище факти актуалізують перед сучасними дослідниками ціле коло остаточно нез'ясованих, концептуальних питань, що потребують конкретних уточнень, а то й нових документально обгрунтованих рішень. Упродовж цілого XVII ст. співіснували, із деякими періодичними суспільно-політичними змінами (кризами), два великих державних утворення: Московське царство та Річ Посполита. Більшість дослідників, у тому числі й російських, доводять, що Московія виникла раніше, ніж сформувалася ії економічна єдність - необхідна умова утворення централізованої держави. Тоді природно виникає питання: чи сталися якісні та

\footnotetext{
531654 р., червня 16 (26). Чигирин. - Універсал Богдана Хмельницького купцям-грекам Павлові і Степанові Юрієвичам на безмитну торгівлю // Там же. - С.66-67.

${ }^{54}$ Цит. за: Маркевич М. Історія Малоросії. - Т.І. - К., 2003. - С.147.

55 Договор (в списке), заключённый турецким султаном с Войском Запорожским и народом русским, касательно торговли на Чёрном море // Собрание государственных грамот и договоров. - Ч.ІІІ. - Москва, 1822. C.444.
} 
принципово нові економічні зміни у країні до кінця XVII ст.? Чи відбулося економічне єднання всіх ії земель із міжнародними торговими центрами де завгодно (наприклад, в Архангельську), але точно не навколо столиці ${ }^{5}$ ? Уважаємо, що ні. Тоді всі запевнення щодо централізації держави, про входження ії в «новий період російської історії» слід розглядати як необгрунтовані?! Навіть один із класиків марксизму-ленінізму (В.Ленін) писав, що тільки з розвитком буржуазних зв'язків могло статися фактичне об'єднання російських земель в єдине ціле. У такому випадку виникає наступне питання: наскільки грунтовними та міцними були такі зв’язки у середині XVII ст., якщо в 1649 р. на загальнодержавному рівні було закріплено кріпосне право? Навіть «вождь світового пролетаріату», на відміну від радянських і сучасних російських істориків, не застосовував поняття «централізована держава» стосовно Московського царства.

За переконанням О.Сахарова, лише з початком XVIII ст. в Росії став помітним процес зародження й розвитку буржуазних відносин ${ }^{57}$. Він наголошував, що «сам по собі державний лад XVII ст.» повністю належав не до «нового періоду російської історії», а ще до «Московського царства», до середніх віків з їх пануванням боярської аристократії. I це тривало до «енергійних реформ початку XVIII ст.» ${ }^{58}$.

I хоч незаперечним фактом $€$ те, що саме в період Хмельниччини дедалі тіснішими ставали економічні взаємини між українцями та московитами, а міста козацького Лівобережжя, такі, як Новгород-Сіверський, Глухів, Ніжин, Гадяч, Ромни й деякі інші, тяжіли до Курська, водночас Миргород і Полтава - до Бєлгорода, Воронежа, Дону, проте твердження дослідників про нібито функціонування у XVII ст. «єдиного всеросійського ринку», а особливо включення до нього України ще до «возз'єднання» ії з Росією, виглядають необгрунтованими та політично ангажованими. Крім того, Московія на той період аж ніяк не «забезпечувала внутрішню та зовнішню безпеку країни» (В.Веселаго).

Присвятивши окремі сторінки історії українських земель, Р.Геллі у своїй монографії «Економіка та матеріальна культура Росії, І6оo-1725» зробив такий висновок: «Диктатура “старшого брата” була не тільки непотрібною, але й контрпродуктивною» 59 .

\section{REFERENCES}

Hellie, R. (1999). The Economy and Material Culture of Russia, 1600-1725. Chicago.

Kasymenko, O.K. (1995). Rosiisko-ukrainski vzaiemovidnosyny 1648 - pochatku 1651 r. Kyiv. [in Ukrainian].

Kotilaine, J.T. (2005). Russia's Foreign Trade and Economic Expansion in the Seventeenth Century: Windows on the Word. Leiden.

Krypiakevych, I.P. (1990). Bobdan Khmelnytskyi. Lviv. [in Ukrainian].

Markevych, M. (2003). Istoriia Malorosii, 1. Kyiv. [in Ukrainian].

Sakharov, A. (1968). Lenin ob osnovnykh etapakh razvitija Russkogo gosudarstva (do otmeny krepostnogo prava). V.I.Lenin $i$ istoricheskaja nauka. Moskva. [in Russian].

7. Serhiienko, H.Ya. (1978). Velykyi istorychnyi akt (Do 325-richchia vozziednannia Ukrainyz Rosiieiu). Kyiv. [in Ukrainian].

8. Serhiienko, H.Ya. (1979). Vozziednannia Ukrainy z Rosiieiu ta yoho istorychne znachennia. Ukrainskyi istorychnyi zburnal, 1, 5-15. [in Ukrainian].

9. Shevchenko, F.P. (1959). Politychni ta ekonomichni zviazky Ukrainy z Rosiieiu v seredyni XVII st. Kyiv. [in Ukrainian].

10. Veselaho, V.V. (1956). Pryntsypy ekonomichnoi polityky Bohdana Khmelnytskoho. Narysy z istorii ekonomichnoi dumky na Ukraini. Kyiv. [in Ukrainian].

\footnotetext{
${ }^{56}$ Хоча у самій Москві економіка швидко розвивалася.

${ }^{57}$ Сахаров А. Ленин об основных этапах развития Русского государства (до отмены крепостного права) // В.И.Ленин и историческая наука. - Москва, 1968. - С.312-313.

${ }_{58}$ Там же. - C.315.

${ }^{59}$ Hellie R. The Economy and Material Culture of Russia, 1600-1725. - Chicago, 1999. - P.643.
} 


\title{
Oleksandr HURZHII
}

Doctor of Historical Sciences (Dr. Hab. in History), Professor,

Chief Research Fellow,

Department of History of Ukraine of the Middle Ages and Early Modern Times,

Institute of History of Ukraine NAS of Ukraine

(Kyiv, Ukraine), oleksandrgurzijoo3@gmail.com

ORCID: https://orcid.org/oooo-oooI-694I-4488

\section{The First Years of "Friendship and Brotherhood" in the Ukrainian-Muscovy Trade of the Mid-Seventeenth Century}

\begin{abstract}
The purpose of the paper is to characterize the difficult relations between the authorities of Ukraine and Muscovy in the field of trade in the middle of the $17^{\text {th }}$ century. The research methodology is based on the principles of historicism and determinism. The author used both general scientific (system analysis, synthesis, analogy, abstraction, generalization) and special-historical (critical work with sources, comparability, problemchronological) methods. Scientific novelty. For the first time, the question of the existence of an all-Russian single market and the inclusion of the national market of Ukrainians is raised based on contemporary sources. Conclusions. In the first years of the National revolution of the $17^{\text {th }}$ century, the withdrawal from the Polish-Lithuanian Commonwealth of a large part of the Ukrainian lands significantly restricted the foreign trade of their inhabitants in the direction of Western Europe, and encouraged it to intensify in the direction of the northern neighbour and eastern states. At this stage of economic development, hetman B.Khmelnytskyi managed to maintain some independence and relatively democratic nature of trade with foreign countries, and to focus the policy on favourable relations with foreign merchants, including Russian, Polish, Lithuanian, Greek, partly Turkish and the Crimean Khanate's ones.
\end{abstract}

Keywords: foreign trade, merchants, Muscovy, Ukraine, Polish-Lithuanian Commonwealth, "Lithuanian side". 